\title{
Multiple Effects of Intense Meteorological Events in the Benevento Province, Southern Italy
}

\author{
Paola Revellino ${ }^{1, *} \mathbb{D}$, Luigi Guerriero ${ }^{1} \mathbb{D}$, Neri Mascellaro ${ }^{1} \mathbb{D}$, Francesco Fiorillo ${ }^{1}$,

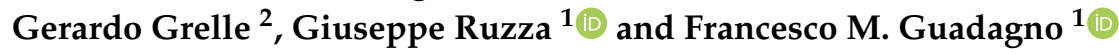 \\ 1 Department of Sciences and Technologies, University of Sannio, 82100 Benevento, Italy \\ 2 Department of Civil and Environmental Engineering, University of Rome "La Sapienza", 00184 Rome, Italy \\ * Correspondence: paola.revellino@unisannio.it
}

Received: 20 June 2019; Accepted: 26 July 2019; Published: 28 July 2019

check for updates

\begin{abstract}
In October 2015, two intense rainfall events hit the central and southern regions of Italy and triggered a combination of different and widespread effects, including floods, landslides, and soil erosion. These outcomes devastated about 68 municipalities of the Benevento province (Campania region), killed two people, and caused millions of euros worth of damage to structures, infrastructures, and agriculture. The town of Benevento was one of the sectors most affected by overflow. Extensive areas characterized by flyschoid outcrops experienced widespread occurrences of soil erosion and landslides, and destructive, high-velocity debris flows (about 50) afflicted areas that had experienced heavy rainfall of higher intensity (total rainfall of $415.6 \mathrm{~mm}$ ). In this study, the characteristics of these rainfall events and related geomorphological processes were determined by (i) analyzing the available rainfall data to identify the spatial pattern, distribution, and statistical characteristics of the two storms and (ii) mapping the storm effects, such as flooded areas, landslide types, and soil erosion. These effects were then related to the spatial distribution of the storms and the local geological and geomorphologic settings that drove their initiation and development.
\end{abstract}

Keywords: rainstorm; landslide; flood; soil erosion; debris flow; Benevento province

\section{Introduction}

The frequency of destructive, storm-induced phenomena in the Mediterranean region is increasing, possibly as a consequence of ongoing climate change e.g., [1-4]. In the last several decades, thousands of victims and huge economic losses worldwide have resulted from landslides and floods induced by intense meteorological events e.g., [5,6]. Therefore, studies on these kinds of events and their impact on urbanized environments have increasingly played a pivotal role in hazard evaluation, risk assessment, and mitigation strategies, as well as the safeguarding of human lives. For instance, Aronica et al. [7] studied the catastrophic event that occurred on 1 October 2009, which induced extensive floods and debris flows on the Ionian side of eastern Sicily (southern Italy) and caused 36 deaths in the village of Giampilieri. On the Tyrrhenian side of eastern Sicily, floods and landslides occurred on 22 November 2011 and caused three deaths in the Saponara village [8]. Similar events transpired on 25 October 2011 and hit different areas of Italy between eastern Liguria and northern Tuscany, causing 13 fatalities [9].

In Italy, the Campania Region has suffered tragic consequences of hydrogeological events e.g., [10-15]: It has experienced the largest number of landslide- and flood-related casualties (2164 casualties from 321 events between 1850 and 2008) in the country [16]. Within the Campania Region, the Benevento province has been historically affected by hazardous phenomena triggered by intense rainfall e.g., [17-19]. In October 2015, two extreme meteorological events hit the province and triggered a combination of different effects, such as floods, landslides, and soil erosion. These incidents devastated about 68 municipalities, killed two people, and caused damages in the amount of $€ 700$ million to 
structures and infrastructures (estimated by the Campania Region Authority) and $€ 1$ billion to local agriculture (according to Italian Farmer Confederation). Parts of the Benevento town and the Tammaro and Calore river valleys were completely flooded e.g., [20]. Many factories in the industrial area of Benevento were damaged or destroyed (e.g., the Rummo pasta factory).

Shallow landslides and extensive soil erosion were triggered throughout the province, and destructive debris flows on the northern slope of the Taburno-Camposauro massif inflicted damage to local roads and buildings [21-23]. Nearly all the croplands of the Benevento province suffered severe soil erosion, which caused the local economy, which is historically based on agricultural production, to incur severe losses.

In this context, this paper describes the characteristics of these rainfall events and their related geomorphological processes. In particular, we analyze (i) the spatial pattern, distribution, and statistics of the two storms using the rainfall data recorded by the Civil Protection's meteorological stations, which are distributed throughout the study area, and (ii) the landslides, flooding, and soil erosions triggered by the storms by comparing them with the local geological and geomorphologic settings to understand the possible spatial control of their initiation and development.

\section{Materials and Methods}

\subsection{Study Area}

The Benevento province has an area of about $2000 \mathrm{~km}^{2}$ and is located in the northeastern sector of the Campania Region in Southern Italy. The province is known for its geological complexity (Figure 1). This complex geology is related to the tectonic history of the Neogene thrust belt structures that form the Apennine chain, which is linked to the northeastward movements of the African-Adriatic plate and has an associated wedge-top/piggyback basin on its top [24-26]. The consequences of this geological activity include the outcropping of Cretaceous-to-Pliocene marine successions and Plio-Pleistocene continental deposits.

Geological, geomorphological, and geostructural features have shaped the landscape, resulting in three main geomorphological domains (Figure 1):

1. The western sector is dominated by high-energy calcareous-dolomitic mountain chains (e.g., the Taburno-Camposauro massif). This part of the province is characterized by steep slopes and sparse vegetation;

2. In the northeastern sector, Miocene-Oligocene clay-rich flyschoid formations crop out and form hilly morphologies. Here, slow-moving landslides are widespread and frequent on slopes with angles that range from $9^{\circ}$ to $14^{\circ}[27,28]$;

3. The southeastern and central part is predominated by fluvial valleys in which the major rivers flow. This section is filled with terrigenous deposits that mainly consist of Plio-Pleistocene clay, sandstone, and conglomerate successions.

The outcropping deposits described above can be divided into 5-group litho-technical sequences, identified according to [18], on the basis of their mechanical and lithological features (Figure 1): (1) Predominantly pelitic sequences (from low to medium degrees of tectonization); (2) predominantly pelitic sequences (high degree of tectonization); (3) rock sequences (from low to medium degrees of tectonization); (4) rock and complex successions (high degree of tectonization); (5) coarse clastic and/or inhomogeneously lithified sequences. This simplification, resulting from a combination of already-existing geological maps and direct field surveys, makes it easier to compare the spatial variation in the lithological nature of terrains with the spatial variation in storm effects.

The Calore is the main river of the province. It flows from southeast to west in a structural valley that is bordered by normal faults with a strike-slip component and associated with at least five orders of river terraces [29]. The main tributaries are (1) the Sabato River, which flows from south to north, and (2) the Tammaro River in the northern sector of the province. 


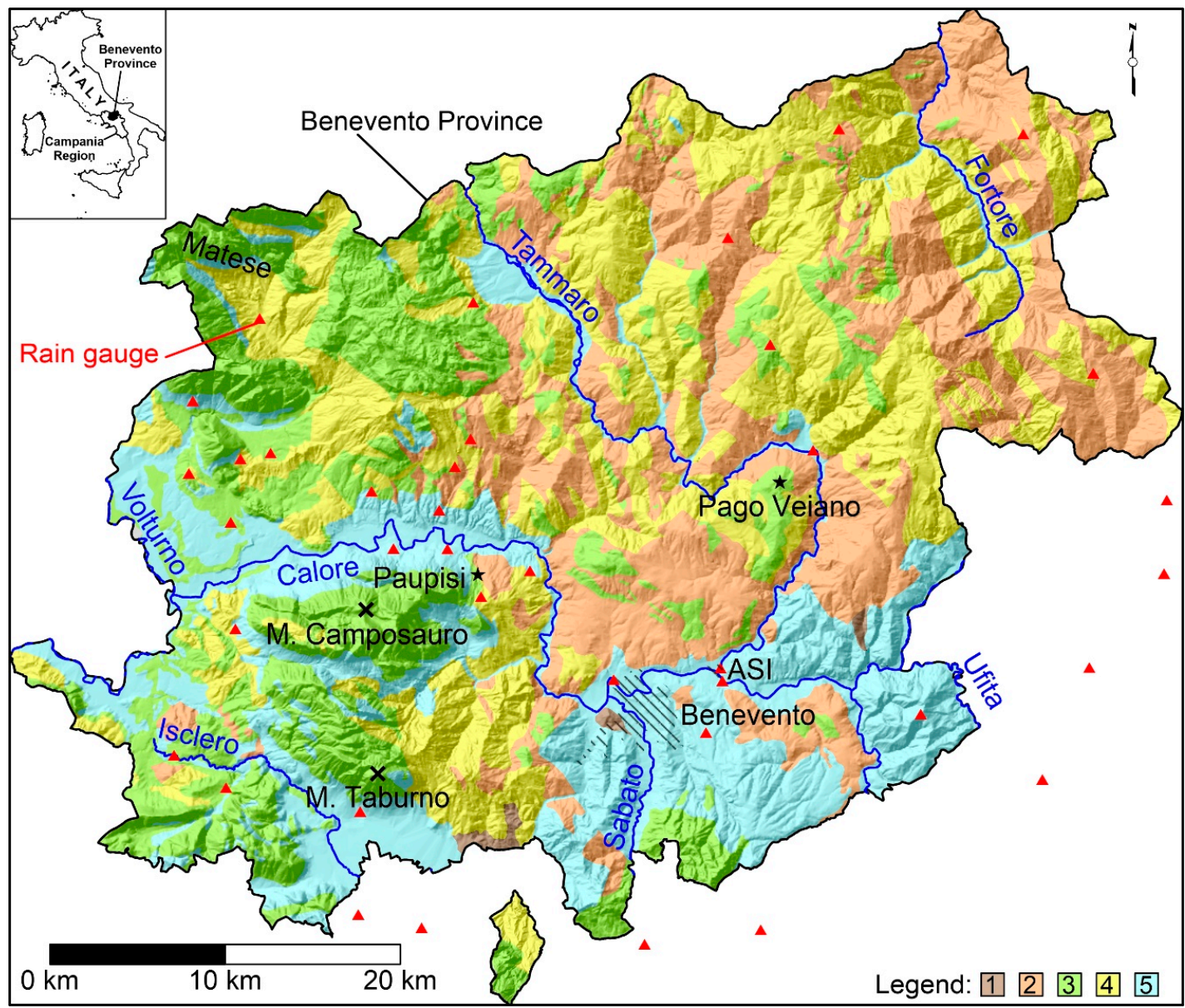

Figure 1. Outcropping of litho-technical sequences in the Benevento province (modified from [18]). Legend: (1) Predominantly pelitic sequences (from low to medium degrees of tectonization); (2) predominantly pelitic sequences (high degree of tectonization); (3) rock sequences (from low to medium degrees of tectonization); (4) rock and complex successions (high degree of tectonization); (5) coarse clastic and/or inhomogeneously lithified sequences. Rain gauges considered for our analysis are reported using red symbols. The industrial area of Benevento (ASI) is labeled.

The Calore valley is a wide basin that has been subjected to many overflow events. Historical data indicate that the main floods were induced by storms concentrated in the catchments of the valley's main tributaries [30], such as the Sabato and Tammaro rivers. On 2 October 1949, the most destructive event occurred when heavy rainfall led to diffuse flooding that destroyed the historical center of the city and affected the middle valley of the Calore River. It caused 20 fatalities and severe damages (from the chronicles of the time).

The study area has a typical Mediterranean climate characterized by hot, dry summers and wet autumns and winters with long rainy periods. December is the rainiest and wettest month, and July is the driest. The annual average rainfall is about $920 \mathrm{~mm}$ [17].

\subsection{Hydrological Data and Statistical Analyses}

The spatial distribution and the temporal evolution of the two storms on 14-15 October and 19-20 October 2015 were reconstructed using data from a network of 52 rain gauges located in the Benevento province and on its contours (see Figures 1 and 2 for location). Of these meteorological stations, 33 are managed by the Agro-meteorological Center (Centro Agrometeorologico Regionale, C.A.R.) of the Campania Region, and they documented both events. The remaining 19 stations are distributed only in the Benevento province and managed by the Campania Region Civil Protection 
(Centro Funzionale Multirischi della Protezione Civile della Regione Campania). To reconstruct the rainfall spatial distribution that characterized both the first and the second storm, we interpolated the total rainfall using a radial basis function in a Geographic Information System (GIS) environment. Data from stations outside of the Benevento province were used to improve the spatial interpolation along the boundary.

The statistical characteristics of annual maxima were investigated by processing the actual data using two distinct procedures. In the first step, each ordered time series was fitted by a distribution function to find the probability of all theoretical values; the second step transformed the resultant probabilities into the $Z$ values of the standard normal distribution [31].

To fit the annual maxima, we used the GEV (Generalized Extreme Value) distribution [32,33]. For this distribution, Equation (1) calculates the cumulative probability, $P$, for values below a specific threshold $(X \leq x)$ :

$$
P(X \leq x)=\exp \left\{-\left[1+\xi\left(\frac{x-\mu}{\sigma}\right)\right]-\frac{1}{\xi}\right\}
$$

where $\xi$ is the shape parameter (dimensionless), and $\mu$ and $\sigma$ are position and scale parameters.

The GEV function obtained by Equation (1) was plotted by applying the Weibull formula:

$$
P(i)=\frac{i}{N+1}
$$

where $N$ is the number of data points in the series, and $i$ is the position in the ordered set of data.

The cumulative probability found by the GEV frequency distribution (Equation (1)) was then transformed in the $Z$ value of the standard normal distribution. The result of this transformation is a symmetric series with a zero mean and a standard deviation equal to 1 [31].

\subsection{Effects of the Storms}

The rainfall events had multiple effects throughout the Benevento province: floods, landslides, and extensive soil erosion damaged agriculture and infrastructures in a wide area. Due to its geological and morphological characteristics, the Benevento province is already a fragile environment that is extensively afflicted by surficial geomorphological processes. For example, the Landslide Index (LI, defined as the percentage of area affected by landslides per unit area) in some sectors exceeds $75 \%$ [18].

We used satellite and aerial images to first map flooded areas, landslides, and soil erosion, and then we created a database of the detected phenomena. Specifically, we used (1) Google Earth ${ }^{\circledR}$ images, for the whole area, taken on 4 November 2015 and (2) EROS-B satellite images taken on 19 October 2015, to map the most damaged sectors of Paupisi village and the Benevento town only. Aerial and satellite images taken after the events were compared with those taken before to determine the type of each mapped phenomenon and identify newly activated slope instabilities and erosional processes. In particular, in order to easily depict the areas affected by soil erosion throughout the whole territory of the Benevento province, we chose circular regions with a diameter of $500 \mathrm{~m}$ as elementary mapping units. These areas were identified at a fixed 1:20,000 scale and depicted as multiple circular regions, which were subsequently dissolved and transformed into a single informative raster. The use of this vector operator allowed us to speed up the mapping processes, although the accuracy of the mapping was lower than that of traditional polyline-based mapping. Given our purpose and the scale of the final map, this accuracy was deemed acceptable.

Additionally, several field campaigns were completed immediately after the storms to validate and improve our inventory map and obtain information about the triggering mechanism and process evolution. A large database of photos taken during the site surveys supported the analysis. The geographic location, the geomorphic layout, and the geological framework were fundamental tools used to specify the nature of the mapped phenomena.

The flooded areas of major river segments of the Calore River were described in a previous mapping study [20]; here, we considered the flooded areas in the entire Benevento province. 


\section{Results}

\subsection{Spatial and Temporal Characteristics of the Storms}

The maps in Figure 2 show the rainfall distribution during the first (Figure 2A) and second (Figure 2B) storm event. The first storm on 14-15 October developed in the NE-SW direction. It principally affected the area surrounding the Taburno-Camposauro massif and the middle Calore river valley, and it elongated toward the upper Tammaro river basin, which was involved in the full extent of the storm. It was characterized by a strong intensity and large extent, covering all of the Benevento province and part of the Avellino province. The center of the maximum cumulative rainfall was located near the Paupisi village, where the total recorded rainfall was $415.6 \mathrm{~mm}$ (Figure 2A). The rain gauge located in Vitulano (labeled B in Figure 2A), which is $3.2 \mathrm{~km}$ from Paupisi, recorded $270.4 \mathrm{~mm}$, a decrease of $145.2 \mathrm{~mm}$ only $3.2 \mathrm{~km}$ from the center of the maximum rainfall. The rain gauge in the Benevento town recorded a cumulative value of $156.4 \mathrm{~mm}$. These data highlight that the higher intensities of the storm were spatially concentrated in a limited area (compared with the total affected area).
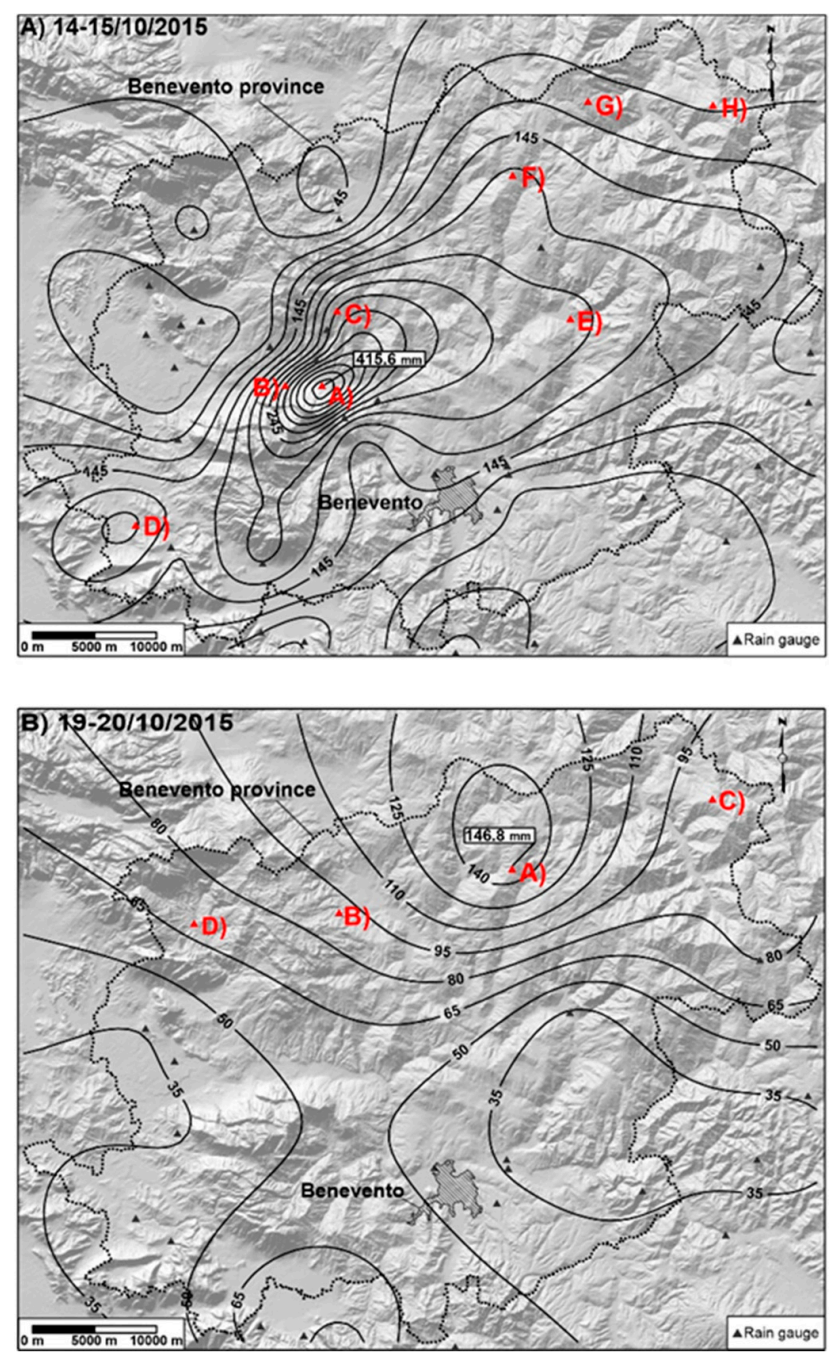

Figure 2. The spatial distribution of cumulative rainfall (black isohyets in $\mathrm{mm}$ ) for (A) the event of 14-15 October (cumulative rainfall from 8:00 p.m. on 14 October to 3:00 p.m. on 15 October) and (B) the event of 19-20 October (cumulative rainfall from 11:00 a.m. on 19 October to 5:00 p.m. on 20 October). The maps label the registered maximum intensity, and the red triangles are the rain gauges selected for temporal analyses of the storms (Figures 3 and 4). The black triangles are the locations of rain gauges. The base map is a $20 \mathrm{~m}$ Digital Elevation Model (DEM, single-sided dimension). 

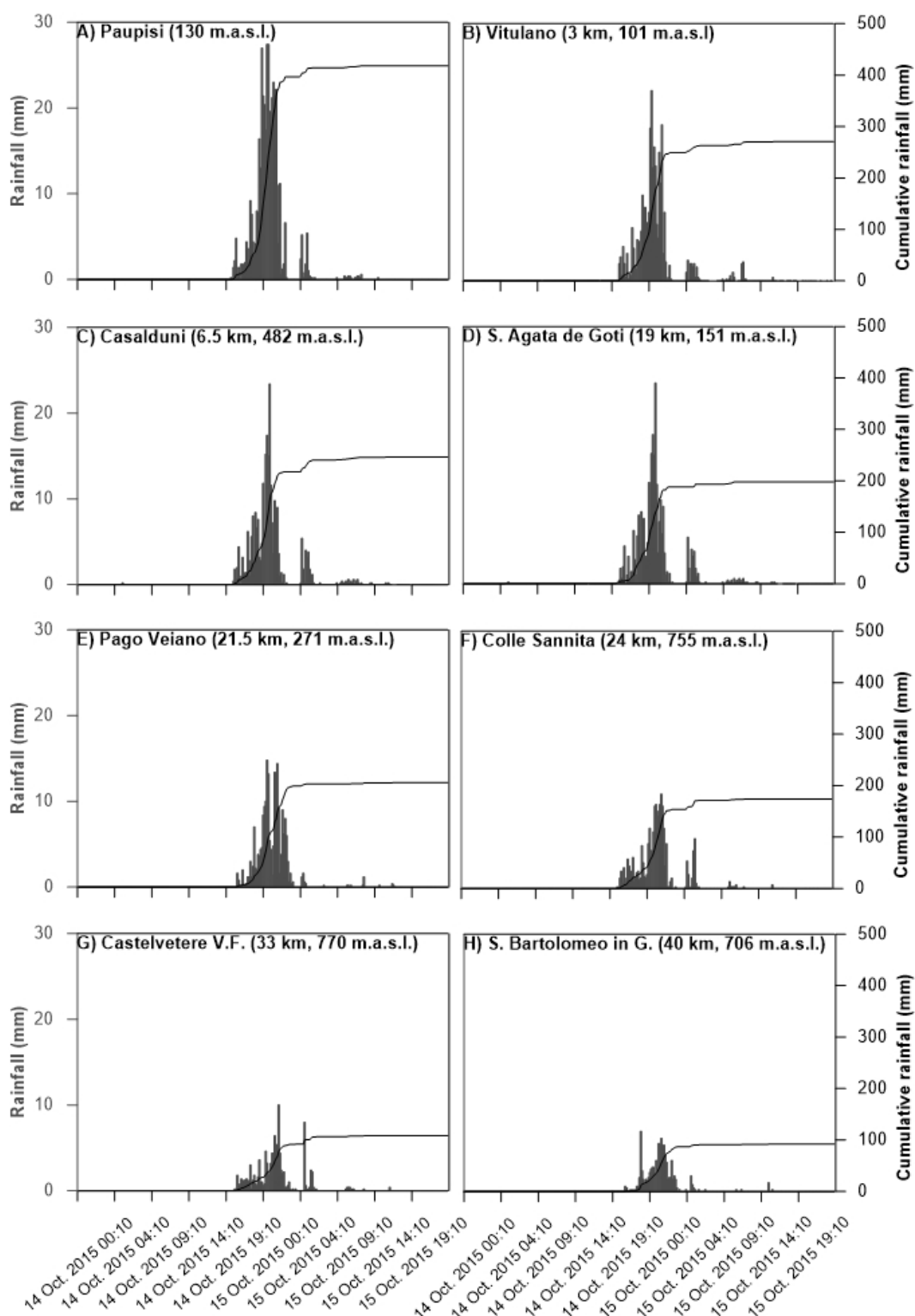

Figure 3. Ten-minute and cumulative rainfall registered during the event on 14-15 October 2015 by some significant stations, starting from the maximum peak of intensity (Paupisi). See Figure 2 for station locations. (A) Paupisi (130 m a.s.l.); (B) Vitulano (3 km, $101 \mathrm{~m}$ a.s.l.); (C) Casalduni (6.5 km, $482 \mathrm{~m}$ a.s.l.); (D) S. Agata de Goti I. (19 km, $151 \mathrm{~m}$ a.s.l.); (E) Pago Veiano (21.5 km, $271 \mathrm{~m}$ a.s.l.); (F) Colle Sannita (24 km, $755 \mathrm{~m}$ a.s.l.); (G) Castelvetere V.F. (33 km, $770 \mathrm{~m}$ a.s.l.); (H) S. Bartolomeo in G. (40 km, $706 \mathrm{~m}$ a.s.l.).

The second storm on 19-20 October was characterized by a lower intensity and shorter duration, and it was mainly concentrated in the northeastern side of the Benevento province along the Tammaro river valley (Figure 2B). The maximum cumulative rainfall occurred in Colle Sannita $(146.8 \mathrm{~mm})$, with $141 \mathrm{~mm}$ occurring in only $4 \mathrm{~h}$. The rain gauge located in Morcone, $15 \mathrm{~km}$ from Colle Sannita, recorded about $90 \mathrm{~mm}$ and a peak of intensity of $15.2 \mathrm{~mm} / 10 \mathrm{~min}$ (Figure 2B). Thus, this storm was less concentrated in a single area compared with the first storm.

The first rainy event, a so-called self-healing V-shaped storm [34] with a mesoscale convective storm system [35], started at around 8:00 p.m. on 14 October and was induced by the development of cyclogenesis [21]. Figure 3 shows the 10-min and total cumulative rainfall of some of the most significant records. The graphs indicate that the rainfall distribution was characterized by two major pulses with a lag time that ranged between a few minutes and several hours. In Paupisi, the first 
pulse had a maximum intensity of $27.4 \mathrm{~mm} / 10 \mathrm{~min}$, which was the maximum intensity registered during this event, while the second pulse occurred a few hours later and had a maximum intensity of about $8 \mathrm{~mm} / 10 \mathrm{~min}$. Along the direction (SW-NE) of storm development, all the rain gauges recorded the second pulse, which was consistently characterized by a lower intensity and shorter duration compared with the first pulse. The first pulse, covering the time span between 10:00 p.m. on 14 October and 4:00 a.m. on 15 October, was the most significant contributor to the flooding event.

The second event on 19-20 October was characterized by a cumulative amount and rainfall intensity that were much lower than those of the previous event. It started at around 11:00 a.m. on 19 October and stopped at around 5:00 p.m. on 20 October. Figure 4 shows the 10-min and total cumulative rainfall recorded by some significant stations. The rainfall distribution had one main pulse, with most of the rain falling within a few hours, and a maximum intensity of $15 \mathrm{~mm} / 10 \mathrm{~min}$ registered by the Morcone rain gauge.
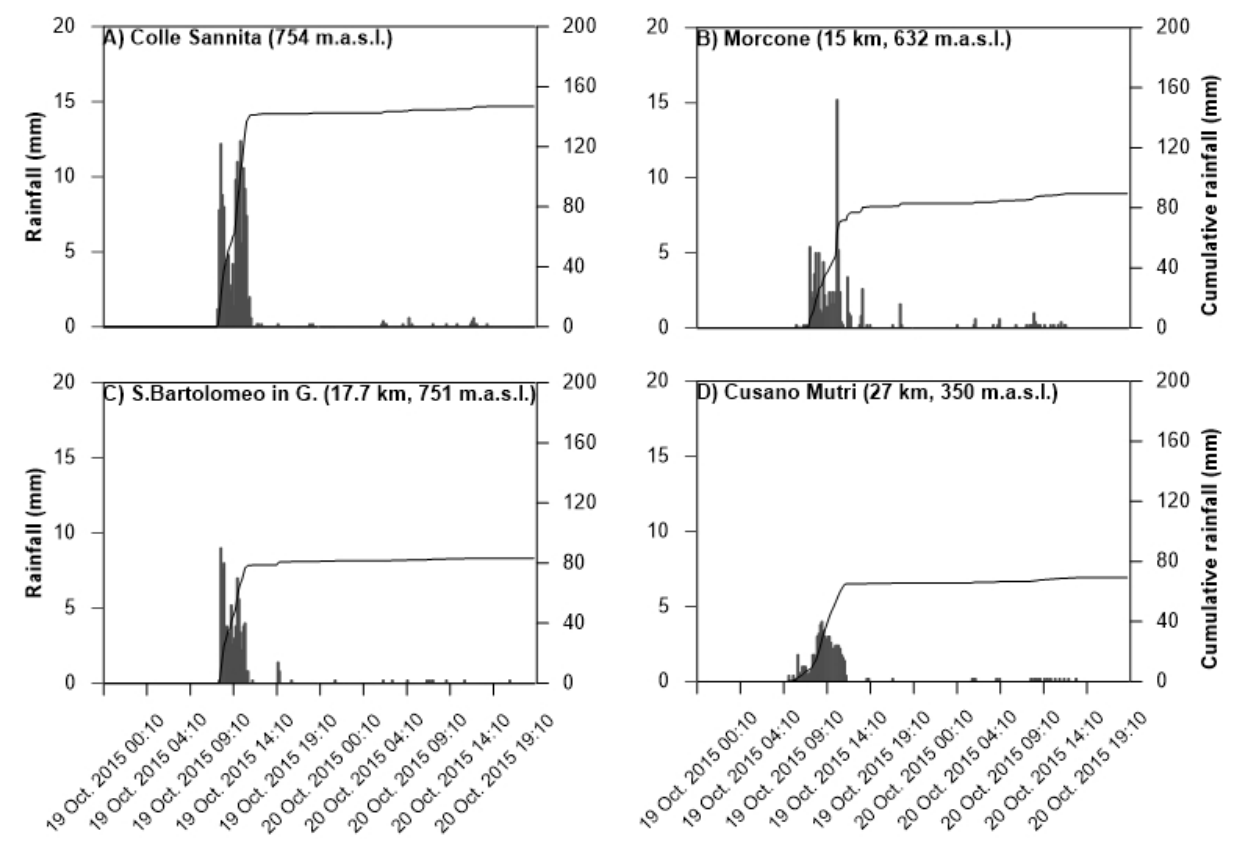

Figure 4. Ten-minute and cumulative rainfall for the event on 19-20 October 2015 recorded by some significant stations, starting from the maximum peak of intensity (Colle Sannita). See Figure 2 for station locations.

\subsection{Statistical Characteristics of the Storms}

During the first storm, rainfall was particularly intense in Paupisi (Figure 3A), but because the available monitoring time series from the Paupisi station covers only the last few years, the data are insufficient for a valid statistical treatment. However, consideration of the entire geometrical and morphological characteristics of the Calore catchment indicates that the flood events in the Benevento city were induced by the rainfall in the Tammaro river catchment. It is very likely that the flooding event downstream of the town was amplified by the huge amounts of rain in the Paupisi area.

For this reason, we analyzed the historical data on extreme rainfall in the Tammaro catchment by using rain gauges located in the basin. The records from these gauges can be considered representative of a part of the catchment, which is $694 \mathrm{~km}^{2}$ wide and has an average ground elevation of $550 \mathrm{~m}$ a.s.l. It should be noted that a dam built during the 1970s subtends $270 \mathrm{~km}^{2}$ of the upper part of the catchment and has changed its hydrological response.

Therefore, statistical analysis focused on the rain gauges with a long historical record, with a particular emphasis on the S. Croce del Sannio and Colle Sannita rain gauges since they are located in the middle-upper zone of the Tammaro catchment, close to each other $(\approx 10 \mathrm{~km})$, and at similar ground elevations (724 and $740 \mathrm{~m}$ a.s.l.). 
Figure 5 shows the time series of annual maxima of rainfall occurring in 1, 3, 6, 12, and $24 \mathrm{~h}$; the mean, the median, and the mean plus two standard deviations $(+2 \sigma)$ are also plotted. For maxima in a 3-h period, the storm of 2015 was the most intense in the historical series. For rainfall maxima in longer periods $(6,12$, and $24 \mathrm{~h})$, the storm of 1949 was the most intense. Both the 1949 and 2015 storms exceed the $+2 \sigma$ value for all of the time series (maximum rainfall in 1, 3, 6, 12, and $24 \mathrm{~h}$ ). In particular, the storm of 2015 has the maximum deviation from the mean rainfall for the 3-h duration $(>4 \sigma)$; the deviation is also high for rainfall accumulated in $6 \mathrm{~h}(>4 \sigma)$. The storm of 1949 reaches the maximum deviation from the mean for the rainfall durations between 6 and $24 \mathrm{~h}$; for a rainfall duration of $12 \mathrm{~h}$, it has a deviation of $>5 \sigma$.

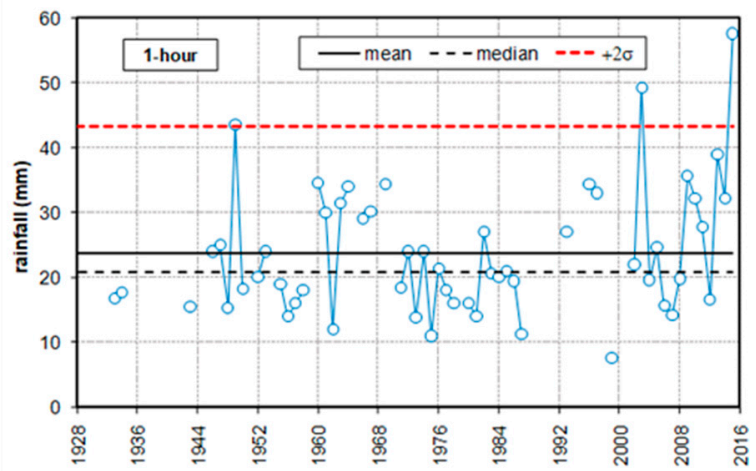

(a)

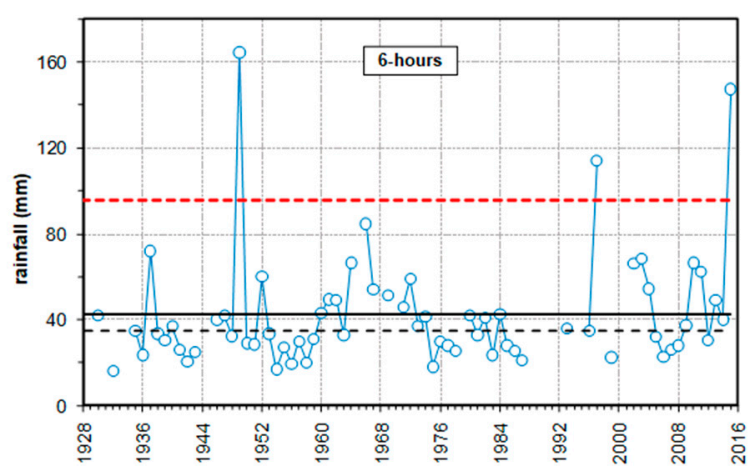

(c)

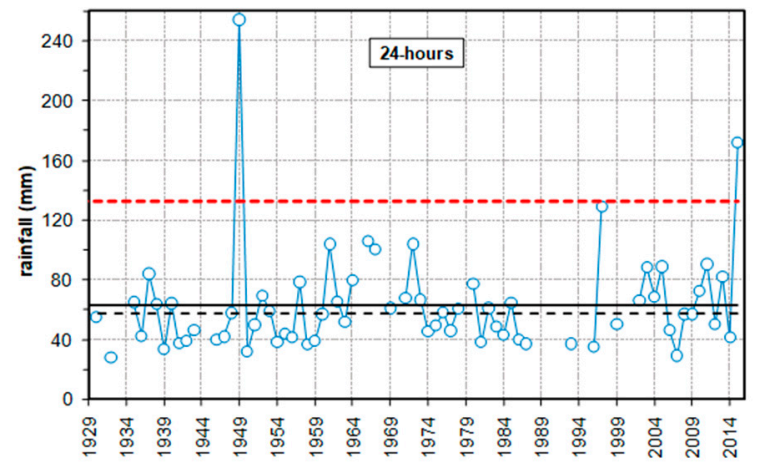

(e)

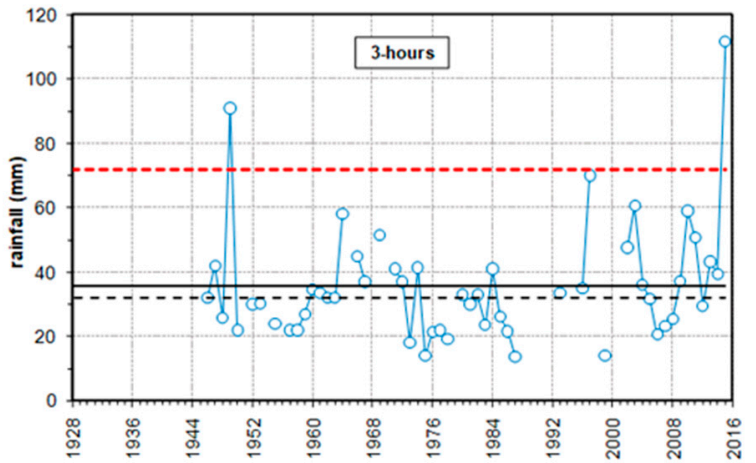

(b)

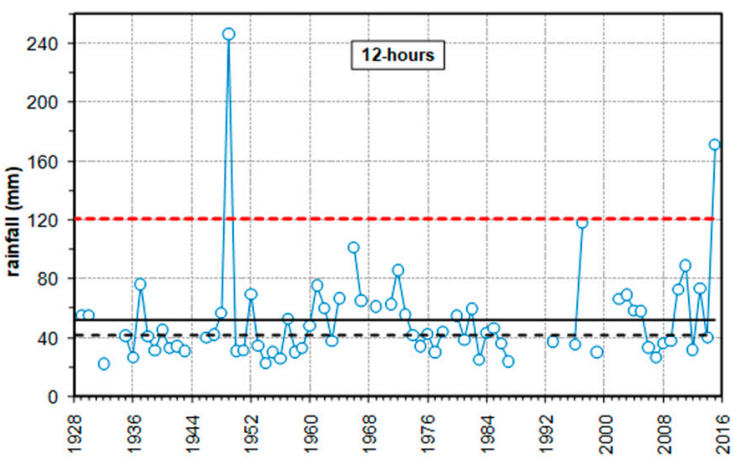

(d)

Figure 5. Time series of annual rainfall maxima in 1, 3, 6, 12, and $24 \mathrm{~h}$ (a-e) from the S. Croce del Sannio rain gauge (724 m a.s.l., from 1929 to 1999) and the Colle Sannita rain gauge (740 m a.s.l., from 2002 to 2015). The mean, median, and mean +2 standard deviations $(+2 \sigma)$ are also shown. Some data are missing. 
Figure 6a shows the GEV function found by Equation (1) for annual rainfall maxima in 6 h; the actual data are plotted by the Weibull formula (Equation (2)). The cumulative probability calculated by the GEV frequency distribution (Equation (1)) was transformed into the $Z$ value of the standard normal distribution (Figure $6 \mathrm{~b}$ ), resulting in a symmetric series with a zero mean and a standard deviation equal to 1 [31].

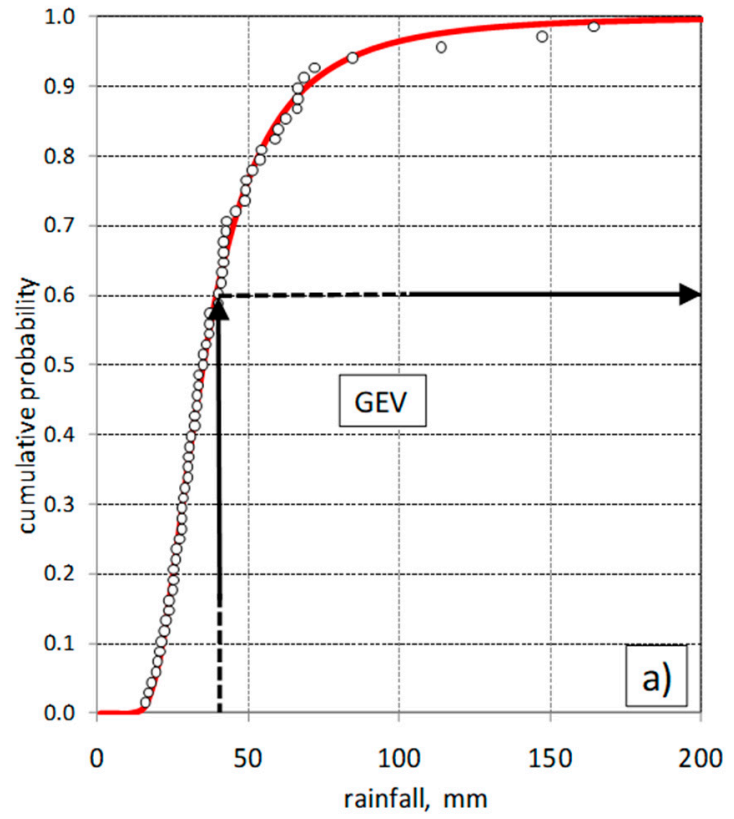

(a)

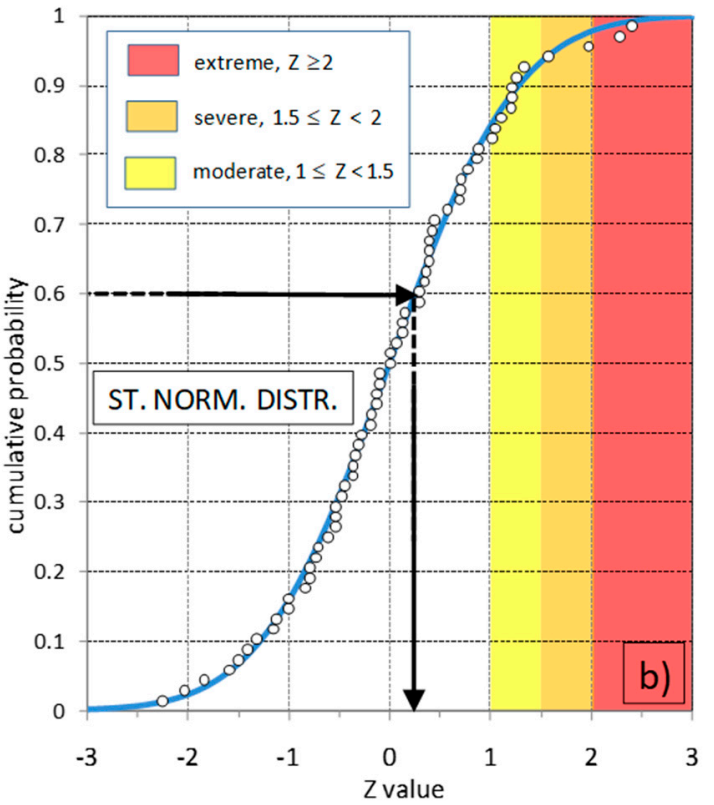

(b)

Figure 6. (a) Six-hour rainfall data series plotted by the Weibull formula and fitted by the Generalized Extreme Value (GEV) distribution; (b) cumulative probability transformed into the $Z$ value of the standard normal distribution transformation.

In the plot of actual data in Figure 5, the deviation from the mean is smaller for the highest values, and it is directly expressed as the $Z$ value. In the transformed series in Figure $6 b$, values that exceed 2 have a probability of occurrence of less than 0.023 . In hydrology, $Z$ values that exceed 2 are typically regarded as extreme events; for example, this classification is used for the drought categories defined by the SPI (Standard Precipitation Index [36]) [31]. The other categories-severe for $1.5 \leq Z<2$, moderate for $1 \leq Z<1.5$, and mild for $0 \leq Z<1$-are similar to those of the SPI in [36].

Because the transformation into the standard normal distribution provides dimensionless values, it allows for a direct comparison between time series of different durations $(1,3,6,12$, and $24 \mathrm{~h})$. Table 1 shows all the storms in the historical series with their 1-, 3-, 6-, 12-, and 24-h maxima categorized as extreme, severe, and moderate. The storm of 2015 is extreme for all rainfall durations $(1,3,6,12$, and $24 \mathrm{~h})$, with the maximum value of $Z$ occurring for a rainfall duration of $3 \mathrm{~h}(Z=2.41)$. The storm of 1949 is extreme for the rainfall durations $3,6,12$, and $24 \mathrm{~h}$ and reaches the maximum $Z$ value for a rainfall duration of $12 \mathrm{~h}(Z=2.59)$. For a 1-h duration, the 2003 storm falls in the extreme category. Storms falling in the severe category did not induce overflow in the catchment. On the basis of historical rainfall data, it appears that storms capable of inducing overflow in the Tammaro catchment (and in the Calore catchment as consequence) fall into the extreme category $(Z>2)$ for a rainfall duration equal to or longer than $3 \mathrm{~h}$. 
Table 1. $Z$ values for the most intense storms recorded in the Tammaro catchment.

\begin{tabular}{|c|c|c|c|c|c|c|c|}
\hline \multicolumn{2}{|c|}{ Categories of Maxima } & Storm Year & $1 \mathrm{~h}$ & $3 \mathrm{~h}$ & $6 \mathrm{~h}$ & $12 \mathrm{~h}$ & $24 \mathrm{~h}$ \\
\hline \multirow{3}{*}{ Extreme } & \multirow{3}{*}{$Z \geq 2$} & 2015 & 2.39 & 2.41 & 2.29 & 2.20 & 2.14 \\
\hline & & 2003 & 2.02 & & & & \\
\hline & & 1949 & & 2.11 & 2.41 & 2.59 & 2.48 \\
\hline \multirow{3}{*}{ Severe } & \multirow{3}{*}{$1.5 \leq Z<2$} & 1997 & & 1.68 & 1.98 & 1.76 & 1.73 \\
\hline & & 1966 & & & 1.59 & 1.55 & \\
\hline & & 1949 & 1.73 & & & & \\
\hline \multirow{17}{*}{ Moderate } & \multirow{17}{*}{$1 \leq Z<1.5$} & 2013 & 1.47 & & & 1.07 & \\
\hline & & 2011 & & 1.10 & 1.25 & 1.37 & 1.12 \\
\hline & & 2010 & & 1.38 & 1.23 & 1.05 & \\
\hline & & 2005 & & & & & 1.09 \\
\hline & & 2003 & & 1.43 & 1.27 & & 1.08 \\
\hline & & 2002 & & & 1.22 & & \\
\hline & & 1997 & 1.06 & & & & \\
\hline & & 1996 & 1.16 & & & & \\
\hline & & 1972 & & & 1.03 & 1.31 & 1.37 \\
\hline & & 1969 & 1.16 & 1.12 & & & \\
\hline & & 1967 & & & & & 1.32 \\
\hline & & 1966 & & & & & 1.41 \\
\hline & & 1964 & 1.13 & 1.35 & 1.23 & & \\
\hline & & 1961 & & & & 1.11 & 1.37 \\
\hline & & 1960 & 1.17 & & & & \\
\hline & & 1952 & & & 1.06 & & \\
\hline & & 1937 & & & 1.35 & 1.32 & \\
\hline
\end{tabular}

\subsection{Analysis of Flooding and Hillslope Processes}

An inventory map of the flooding and hillslope processes produced by the storms was compiled for the whole province (Figure 7) to reconstruct their distribution pattern. Table 2 summarizes the morphometric characteristics and features of the effects that were inventoried in the study region.

\subsubsection{Flooding}

The first storm caused the overflow of the Calore River and had a sudden peak induced by the water received from the Tammaro River-a right-bank tributary-and by the minor tributaries upstream and downstream of the town of Benevento. Upstream, the overflow started in the middle course of the Tammaro River and propagated along the segment of the Calore River that crosses the city of Benevento. At almost the same time, inundations occurred along the middle-lower course of the Calore before the propagation of the flood wave upstream (Figure 7). The evolution of the process was partly influenced by the lamination effect of the Campolattaro dam. The rivers' responses were very rapid according to a comparison of the rainfall data and water stream levels registered by the Ponte Valentino and Pago Veiano monitoring stations, which are respectively located next to the confluence between the Tammaro and the Calore rivers in the industrial area and along the lower course of the Tammaro river (see Figure 7 for location). The storm did not damage these two stations. The Ponte Valentino storm hydrograph (Calore River) shows a lag time of about $4 \mathrm{~h}$ (Figure 8A), while the Pago Veiano storm hydrograph (Tammaro River) indicates a lag time of about $3 \mathrm{~h}$ (Figure 8B). From these lag times, the flooding event is defined as a flash flood. Additionally, the graph in Figure 8A indicates that, in the town of Benevento, the maximum stage and therefore the maximum extent of the area affected by the flood were reached at around 7:00 a.m. 


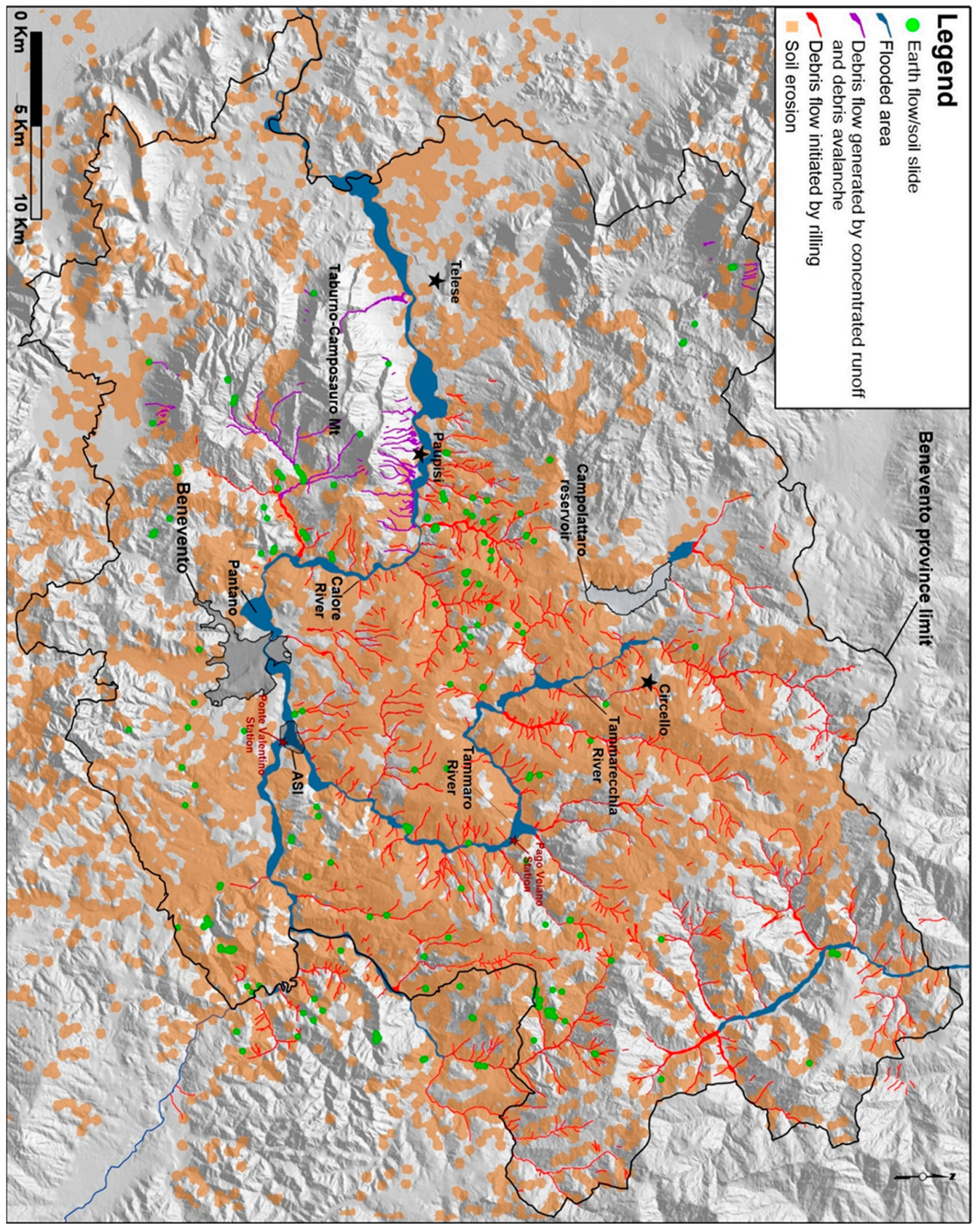

Figure 7. Inventory map of the hydrogeological effects of the storms on 14-15 and 19-20 October 2015 in the Benevento province.

Table 2. Main morphometric features of the flooding and hillslope processes. F, Floods; SE, Soil Erosion; EF, Earth Flow; D, Frun; Debris Flows generated by concentrated runoff; D, Fril; Debris Flows initiated by rilling.

\begin{tabular}{cccccccc}
\hline $\begin{array}{c}\text { Storm } \\
\text { Effects }\end{array}$ & Number & $\begin{array}{c}\text { Area } \\
\left.\mathbf{( k m}^{\mathbf{2}}\right)\end{array}$ & $\begin{array}{c}\text { Source } \\
\text { Height Range } \\
\mathbf{( m} \text { a.s.l.) }\end{array}$ & $\begin{array}{c}\text { Transport } \\
\text { Distance } \\
\mathbf{( m )}\end{array}$ & $\begin{array}{c}\text { Source } \\
\text { Slope } \\
\text { Angle }\left({ }^{\circ}\right)\end{array}$ & $\begin{array}{c}\text { Deposit } \\
\text { Thickness } \\
\mathbf{( m )}\end{array}$ & $\begin{array}{c}\text { Erosion } \\
\text { Thickness } \\
\mathbf{( m )}\end{array}$ \\
\hline F & - & 43 & - & - & - & - & - \\
SE & - & 930 & - & - & - & - & up to 1.5 \\
EF & 264 & - & - & - & - & - & - \\
DFrun & $\approx 50$ & 1.3 & $350-1000$ & $100-7800$ & $10-40$ & up to 1.0 & up to 2.0 \\
DFril & $>200$ & - & $100-900$ & $50-2000$ & $5-15$ & $0.1-1$ & $>1$ \\
\hline
\end{tabular}




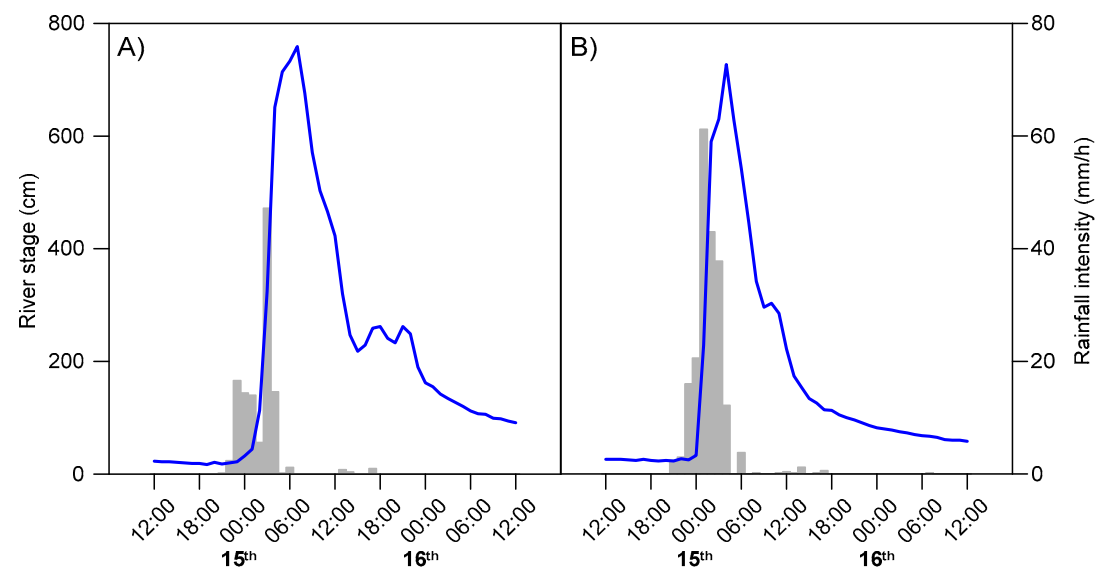

Figure 8. Storm hydrographs of the (A) Ponte Valentino (close to the ASI area) and (B) Pago Veiano stations. Figure 7 shows the station locations.

The overflow of the Tammaro and Calore rivers damaged Benevento's industrial area, which is downstream and near the confluence of these two rivers. In this area, the water reached an estimated maximum level of $9.5 \mathrm{~m} \mathrm{[20]} \mathrm{and} \mathrm{destroyed} \mathrm{important} \mathrm{local} \mathrm{infrastructures} \mathrm{and} \mathrm{factories} \mathrm{(Figure} \mathrm{9A).}$ Further downstream, some of the most damaged zones include a sector of the historical center of Benevento (Figure 9B) and the area named "Pantano" (Figure 9C,D), which means swamp-a clear reflection of its history.

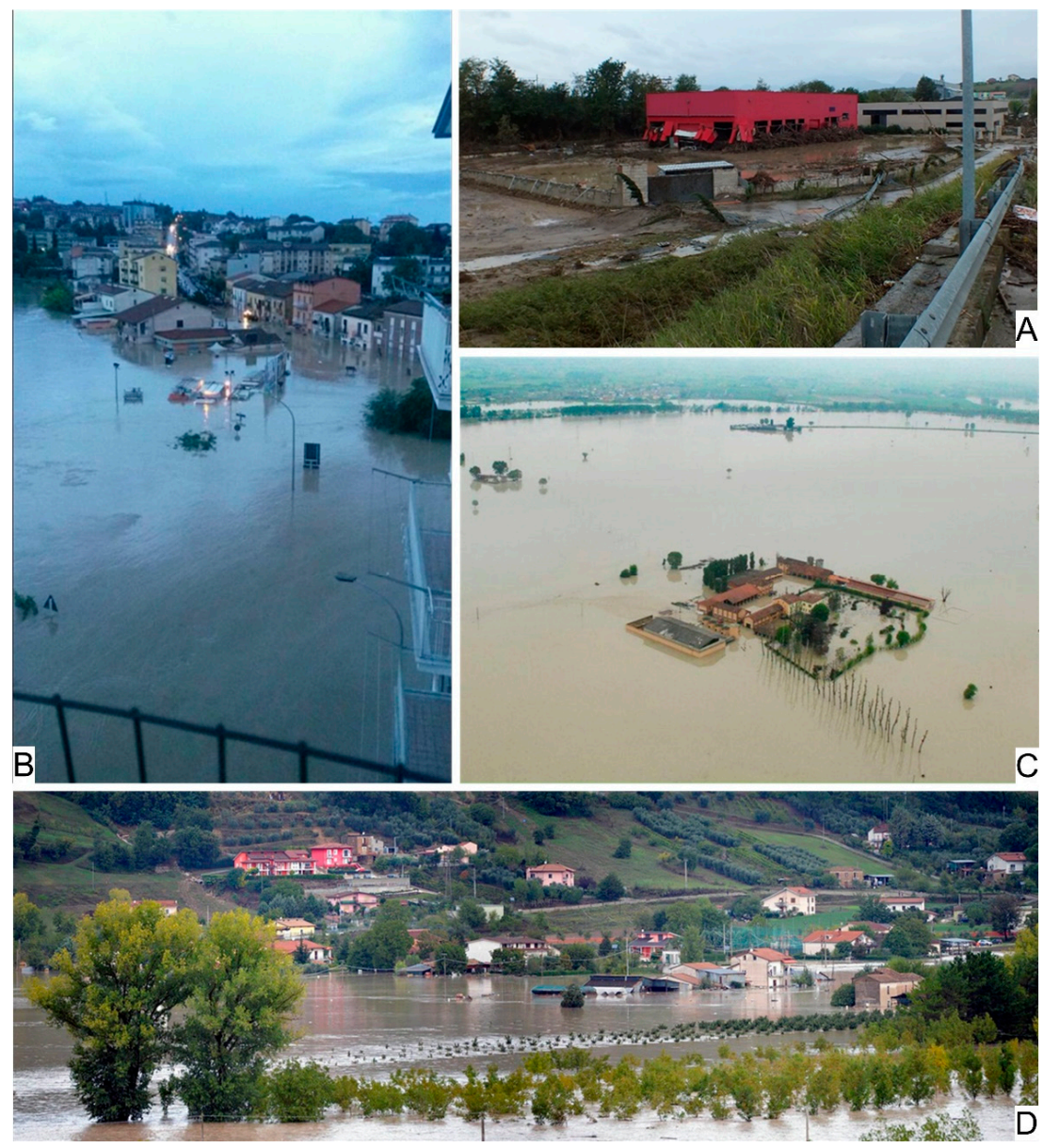

Figure 9. Overflow of the Calore river: (A) Damages in the industrial area of Benevento; (B) flooding at the "Ponticelli" locality, Benevento town; (C) and (D) flooding at the "Pantano" locality, Benevento town. 
The flooded area was mapped by comparing satellite images taken a few days after the events of 15 October with available images taken prior to the storm. The highest water level recorded was established using field surveys and measurements, such as the evidence of flood marks on bridges (Figure 10). The highest values (also according to specific morphologies) are over $9 \mathrm{~m}$ in the riverbed areas, while, in the flooded areas, the water level reached values higher than $3 \mathrm{~m}$. Overall, the flooded area along the course of the Calore River amounts to about $43 \mathrm{~km}^{2}$, of which about $2.0 \mathrm{~km}^{2}$ is urbanized.
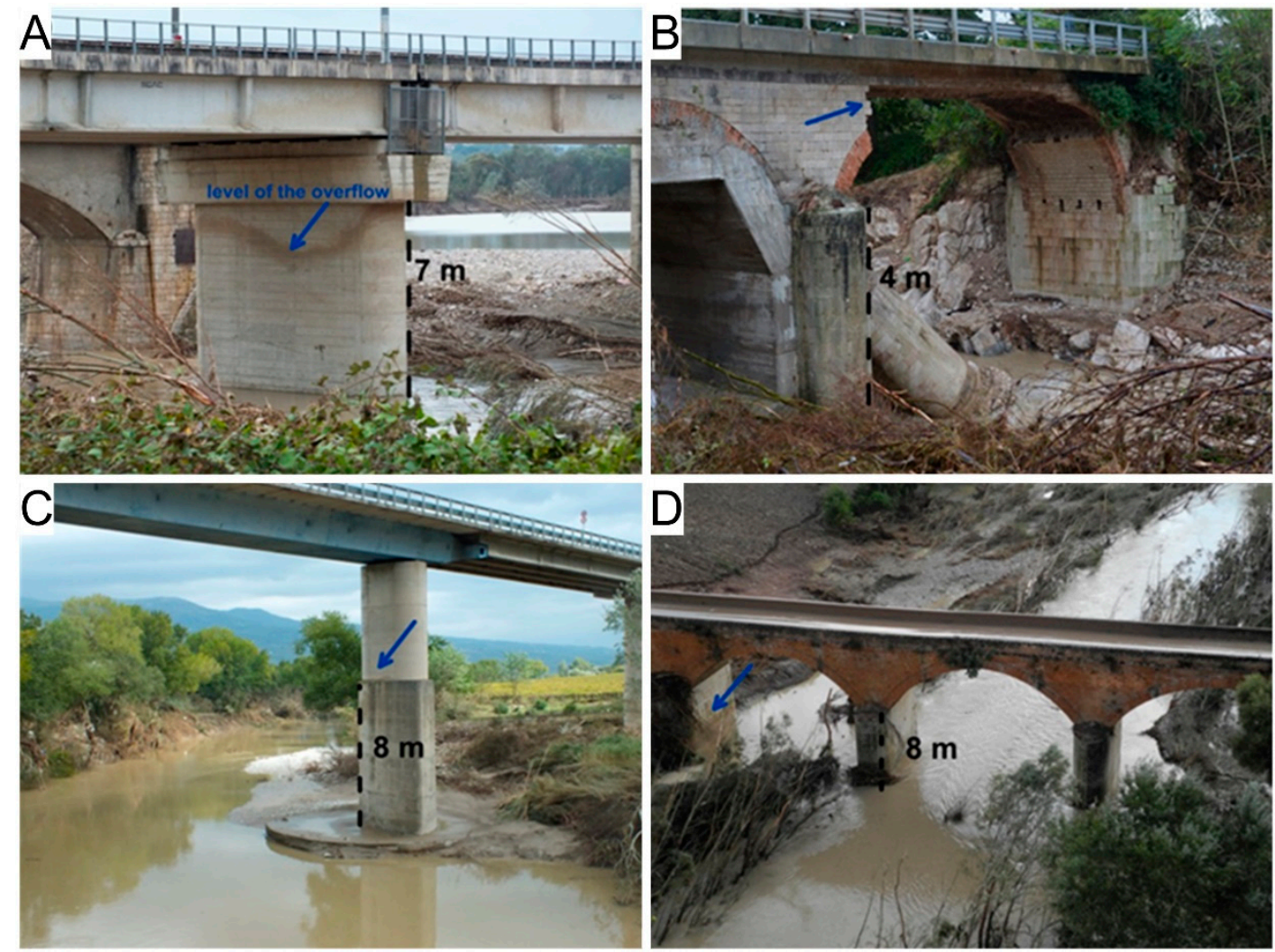

Figure 10. River stage during the overflow of the Tammaro and Calore rivers and Tammarecchia torrent, evidenced by flood marks on bridges, in different places across the Benevento province: (A) The Tammaro river in the industrial area (ASI) of Benevento; (B) the Tammarecchia torrent in Circello; (C) the Calore river in Paupisi; (D) the Tammaro river southwest of Circello.

\subsubsection{Soil Erosion}

As shown in Figure 7, erosional processes occurred extensively throughout the whole province, even though they were concentrated around the NE-SW axis of the storm. Figure 7 is a comprehensive map of both the linear and surface erosion that resulted from the two storms. The soil erosion in the map includes sheet, rill, and gully erosion, resulting in a total affected area of about $930 \mathrm{~km}^{2}$. Most of the affected area is devoted to agricultural use, especially for the production of wine, oils, and cereals.

The combination of the two intense rainy events, which occurred during the autumnal plowing of fields (when their susceptibility to erosive phenomena is at a maximum), produced evidence of microand macroscale soil erosion, as well as morphological and topographic changes to the ground surface. The erosional processes were more severe where flyschoid and clayey sequences crop out. Field analysis showed that, in many cases, soil erosion removed approximately $20-50 \mathrm{~cm}$ of soil as a result of the development of rills (Figure 11A), sheet (Figure 11B), and gullies (Figure 11C). Gully erosion occurred consistently along pre-existing channels, which enlarged and deepened by up to 1.5-2.0 $\mathrm{m}$ (Figure 11D). Erosive flooding and sediment deposition on floodplains were also observed along the main river courses that were subjected to floods (Figure 11E,F). 

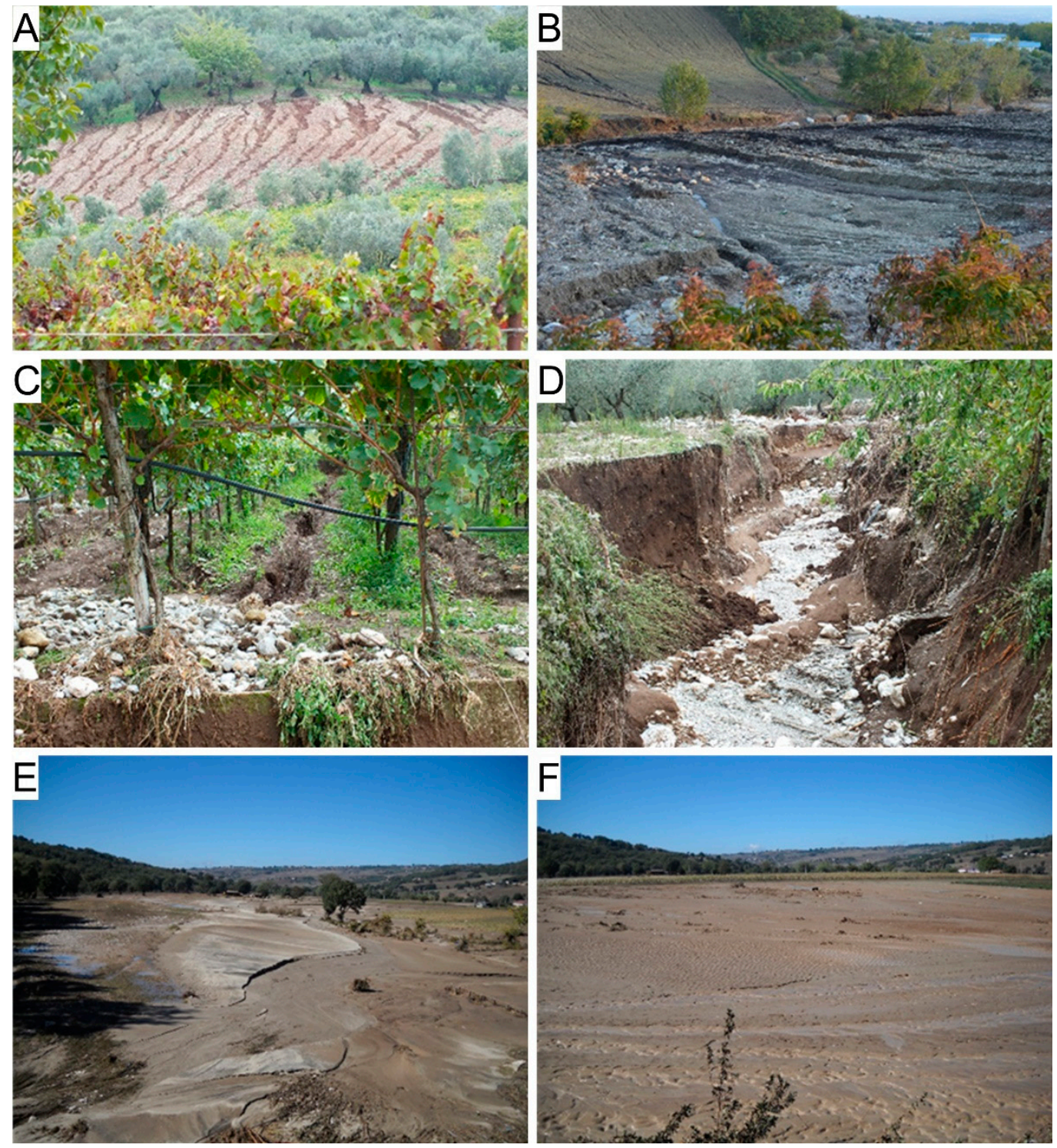

Figure 11. Erosional processes along slopes and floodplains: (A) Concentrated rill erosion; (B) rill and sheet erosion on a cultivated slope; (C) gully erosion in a wine groove; (D) gully erosion along a pre-existing channel; (E) erosive flooding on a floodplain; (F) sediment deposition along the floodplain.

\subsubsection{Slope Instabilities}

The rainy events triggered a number of slope instabilities by different mechanisms, which are related to the geological and morphological setting of the territory. Specifically, very high velocity landslides, such as debris flows and debris avalanches, developed along the steep slopes of the calcareous massifs (litho-technical sequence \#3 in Figure 1; Taburno-Camposauro Mt. in Figure 7), while first-order or reactivated earth flows and debris slides, from slow-moving to moderate-velocity, were triggered on clayey-flyschoid hillsides (litho-technical sequences \#1, \#2, and \#4 in Figure 1). These landslides are indicated on the inventory map in Figure 7. To better clarify the triggering mechanism, we classified landslides as [37] (1) earth flows, debris slides, and debris avalanches and (2) debris flows generated by runoff or initiated by rilling.

Earth flows (1) include both first-order and reactivated landslides that were identified by field surveys and a comparison between pre- and post-event Google Earth images (Figure 12A). It should be noted that because of the limited extent of most earth flows and for scaling requirements, the map in Figure 7 shows only their location, and no morphometric parameters or detailed maps of earth 
flows were produced. Earth flows were mostly triggered in the eastern and central sector of the map, and they were frequently associated with debris flows initiated by rilling. Soil and debris slides were identified as shallow landslides characterized by the translational movement of colluvial soil on a well-defined shear surface. Besides being associated with earth flows, debris slides were located, along with debris avalanches, in the Taburno-Camposauro mountain area, where rocks are covered by a soil mantle with variable thickness that is generally less than a few meters. Overall, 264 earth flows, debris slides, and debris avalanches were mapped, and most of the identified flows were reactivations of pre-existing earth flow deposits located at outcroppings of flyschoid formations. Debris avalanches were rare and have occurred only on the southern slopes of Matese Mt.
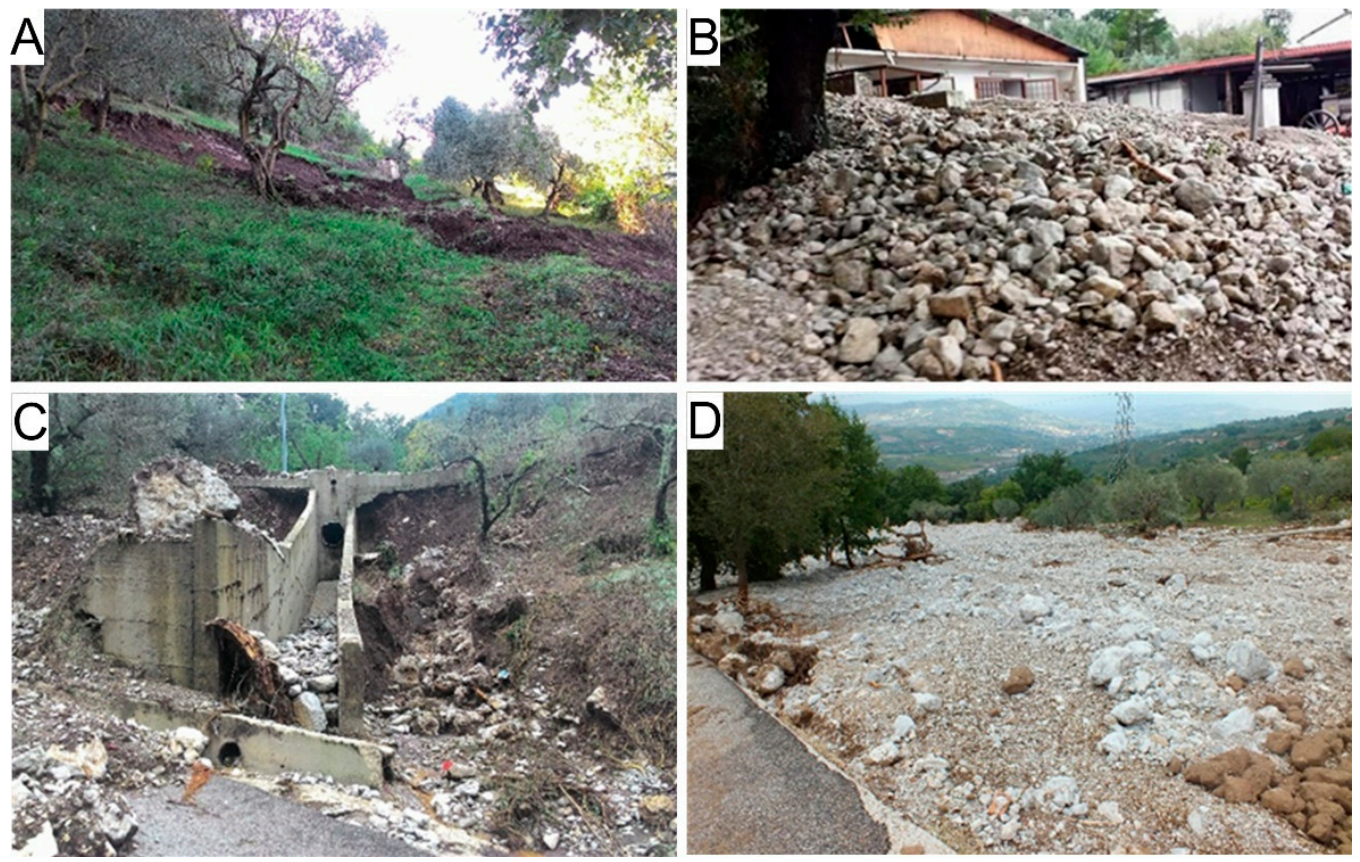

Figure 12. Slope instabilities triggered on slopes: (A) Earth flow; (B) runoff-generated debris flow in the town of Paupisi; (C) poorly sized work in a channel; (D) runoff-generated debris flow deposit.

Debris flows (2) were mapped from the evidence of mass springing in pre-existing creeks and paths with entrained debris, soil, and woody debris, which increase the volume and erosive capability of debris flows. For each debris flow, the source area, the flow path, and the deposit fan were mapped and then validated in the field to improve mapping accuracy. In order to highlight differences in the initiation environments and predominant sources and types of debris, we identified two main debris flow initiation mechanisms, although there were other minor and associated mechanisms (e.g., debris flow initiation from landslides). More specifically, we differentiated between (i) debris flows generated by concentrated runoff, in which debris that has accumulated in pre-existing, steep gullies or first-order drainage channels is mobilized and transported by a surge of concentrated water [38], and (ii) debris flows initiated by rilling, in which erosional processes that are organized in rills and microchannels remove colluvium and soils from the topsoil [39].

Runoff-generated debris flows (i), consisting of carbonate blocks and boulders in a soil matrix, mainly occurred along the steep gullies of the Taburno-Camposauro calcareous massif at night on 14 and 15 October 2015. They were mapped in detail using the results of several field surveys and EROS-B satellite images taken after the storms. Such mass movements have no historical documented precedents in this area. Dozens of debris flows hit the villages of Paupisi and Solopaca, where the rain gauges recorded the highest cumulative value of rainfall, and buildings and infrastructures were destroyed (Figure 12B). The effects were probably amplified by the lack of periodic gully maintenance, which led to channel obstruction by vegetation, or by the poorly sized works often present at road 
crossings or other linear infrastructures (Figure 12C). In this context, the triggering mechanism was similar to that which occurs in an alpine environment e.g., [40,41]. Segments of the debris flow source channel were located between 350 and $1000 \mathrm{~m}$ a.s.l. and had slope angles of $10-40^{\circ}$ on the northern slope and around $20^{\circ}$ on the southern slope. After entering the gullies, debris flow traveled for hundreds of meters; the travel path length ranged between $\sim 100$ and $7800 \mathrm{~m}$. Some debris flows triggered along the northern side of the Taburno-Camposauro Mt. reached the Calore River and provided readily available sediment for fluvial transport. These debris flows deposited parts of the coarse material in cultivated fields (Figure 12D) that are located at the base of the slope. Other parts reached the SS322 national road.

Debris flows initiated by rilling (ii) were mainly located in the eastern sector of the study area on clayey and gentle hillslopes. As is well known, rills are typically linear erosional landforms (i.e., microchannels) with a maximum width and depth of a few tens of centimeters [42] generated by the activity of flowing water. Moreover, they are ephemeral features that tend to disappear soon after their formation [39]. Field observations indicated that the source area of each debris flow was characterized by a specific spatial organization of coalescing rills (Figure 13A). Our interpretation of the process is that the coalescence of more rills flowing in a pre-existing or newly formed creek induced erosional processes at the gully head that propagated downstream, leading to the development of the debris flow. Debris flow development reshaped the gullies with drastic changes in geometry that induced sediment transport downstream (Figure 13B) and the formation of very thin and large debris fans (Figure 3B). Field observations indicated that the thickness of the debris fan varied from tens of centimeters to around $1 \mathrm{~m}$. The thickness of the eroded material and gully deepening was greater than $1 \mathrm{~m}$. All mapped debris flows initiated by rilling occurred on clayey and flyschoid slopes characterized by very low slope angles $\left(5-15^{\circ}\right)$, and the runout distances ranged from a few tens of meters to a few kilometers and seem to be related to the availability of erodible material and the slope morphology.
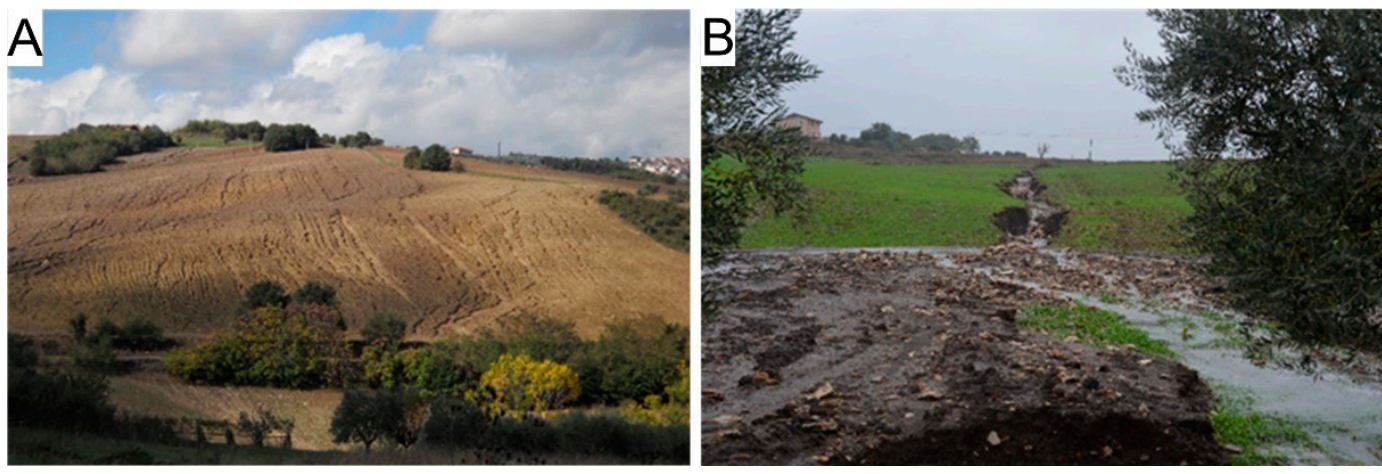

Figure 13. Debris flows initiated by rilling: (A) Coalescing rills; (B) eroded gully and initial part of debris depositional fan area.

\section{Discussion}

According to the distribution of rainfall data, a cumulative rainfall value higher than $100 \mathrm{~mm}$ occurred in an area of about $2000 \mathrm{~km}^{2}$ during the first storm, and it was mostly concentrated in the Benevento province (Figure 2a). In particular, the rainfall on 14-15 October 2015 exceeded $140 \mathrm{~mm}$ in $4 \mathrm{~h}$ in a wide section of the Tammaro catchment, and it caused the overflow of the Calore river downstream. The rainfall in this catchment was extreme for up to $24 \mathrm{~h}$ (Table 1), but it reached the maximum deviation from the mean for a duration of $3 \mathrm{~h}(Z=2.41)$ and maintained its intensity for up to $6 \mathrm{~h}(Z=2.29)$. After the dam was built in the median sector of the catchment, the hydrological response of the Tammaro river changed, and only $424 \mathrm{~km}^{2}$ (of a total catchment area of $694 \mathrm{~km}^{2}$ ) contributes to river discharge. It is interesting to observe that the 1949 storm occurred before the dam was constructed, and its rainfall had a different temporal distribution: In October 1949, the whole catchment contributed to river discharge, and the flood was induced by the rainfall accumulated 
between $6(Z=2.41)$ and $12 \mathrm{~h}(Z=2.59)$. The soil erosion and landslide effects of the 1949 storm are not well known, whereas the flood in the Benevento town was extensively documented by photos and eyewitnesses.

Although the cumulative value of rainfall for the Benevento province is very high, there is not a complete spatial correspondence between its distribution and the distribution of debris flows initiated by rilling and erosional processes. It seems that debris flows initiated by rilling and the accelerated soil erosion are mostly controlled by the geological nature of the outcropping sequence and by land use. Comparison of their distribution with the litho-technical maps in Figure 1 suggests that they developed where predominantly pelitic sequences crop out (litho-technical sequences \#1 and \#2 in Figure 1). Moreover, all the mapped debris flows initiated by rilling correspond with locations of cultivated fields (especially grain, olive groves, and vineyards). The formation of rills, in fact, is probably influenced by the agricultural use of soil, which facilitates the runoff of water in pre-existing microchannels.

The two identified conditions for the initiation of debris flows reflect the different extents and shapes of catchments. Runoff-generated debris flows have a drainage area that extends along their path but is very narrow and steep, as observed in other areas e.g., [38]. Conversely, debris flows initiated by rilling have large catchments with hilly slopes. In this study, no correlation was observed between the exposure of the slopes and the mapped rainfall-induced phenomena. This is probably related to the unusual amount of rainfall. Additional features characterize debris flows initiated by rilling. Our analysis shows that all the coalescent rills have same and repeated shapes. Figure 14 outlines the observed structure (i.e., arrangement) of rills that form the source area of the flows. Specifically, the different patterns of coalescent rills, which are evidence of different morphometric parameters, are (i) dendritic arrangement "a", which is the manifestation of rills on a concave slope that developed symmetrically along the main creek; (ii) subparallel rill systems " $b$ " developed on planar slopes along and parallel to the direction of the main creek; (iii) subparallel rill systems " $c$ ", which are orthogonal to the main creek; and (iv) subparallel rill systems " $\mathrm{d}$ ", which outflow to a high-order gully (" $\mathrm{e}$ "). The fans of debris flows initiated by rilling are large (a few tens of meters) and very shallow because of the low permeability of the mud-rich transported material [43].

Slope instabilities, such as earth flows, are not as numerous as expected. Previous rainy events similar to the October 2015 storm but occurring in winter triggered and reactivated thousands of landslides in the same area e.g., $[18,44]$ instead of the several hundred observed in the 2015 case. This could be connected to the period of occurrence of the storms, i.e., middle October, during which the maximum soil moisture has not yet been reached [17].

On the other hand, the great diffusion of erosional processes that developed on the slopes has to be connected to the intensity characteristics of the storm. In the Tammaro catchment, the rainfall reached the 1-h maximum of the historical series, with $57.6 \mathrm{~mm}$ recorded at the Colle Sannita rain gauge. With the GEV distribution, the estimated probability of occurrence is 0.008 , which corresponds to a return time of 98.5 years. This high intensity occurred in a wide portion of the Tammaro catchment. At Pago Veiano, the maximum rainfall was $61.2 \mathrm{~mm}$, but the available records form a short time series, which precludes a reliable statistical analysis. Other sectors of the Calore catchment are similarly restricted by the absence of long historical data series; thus, the estimation of the magnitude of the hydrological events is also limited in these areas. In fact, the highest rainfall intensity was recorded on the west side of the Tammaro river in a small catchment tributary of the Calore river downstream of the Benevento town; here, the 1-h rainfall intensity reached $88.6 \mathrm{~mm}$ (Casalduni rain gauge) and $114.0 \mathrm{~mm}$ on the steep slopes of Camposauro ridge (Paupisi rain gauge), where spectacular erosion processes took place. Thus, extreme rainfall intensity for a short duration induced the runoff phenomenon along clayey slopes, and this explains the wide diffusion of the above-described erosional processes. 


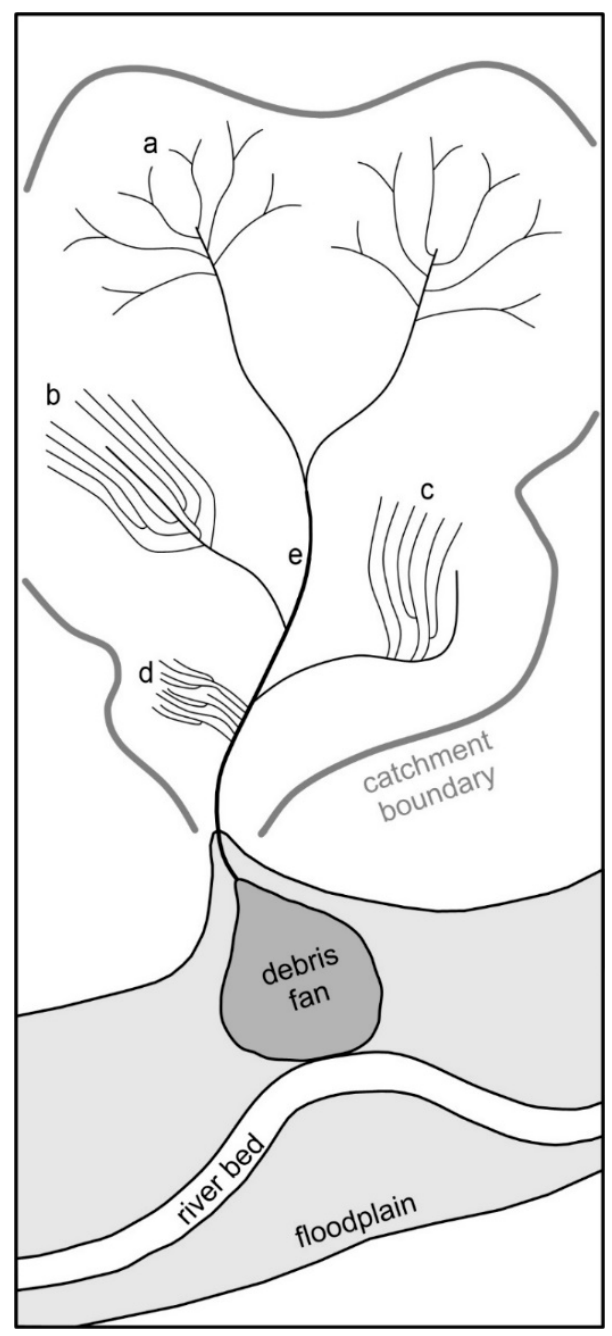

Figure 14. Schematic reconstruction of typical morphological structures of coalescent rills that induce debris flows identified in the study area: (a) Dendritic arrangement; (b) subparallel rill systems, parallel to the direction of the main creek; (c) subparallel rill systems, orthogonal to the main creek; (d) subparallel rill systems, directly flowing into a high-order gully (e).

\section{Conclusions}

The Benevento province has been hit by extreme hydrological events several times in the last century, and such events have caused multiple flooding and hillslope processes in large areas. Hillslope and hydrological processes were particularly intense after the two most intense historical storms on 2 October 1949 and 14-15 October 2015, with the latter followed by a second intense storm on 19-20 October 2015. Both events caused destructive floods along the Calore river, as well as landslides and erosional processes, which can be reconstructed in detail only for the more recent events of 2015 .

As a consequence of the prevalent hilly morphology of this catchment, a limited orographic effect transpired, and rainfall in the first 2015 storm was intense over a wide area; the rainfall that accumulated in 6-12 h was especially intense at two distinct rain gauges (Colle Sannita and Pago Veiano), and the maximum deviation from the mean was reached by the 3-h rainfall.

Our analysis shows that landslides and erosional processes tended to be concentrated in the areas affected by intense rainfall over the entire Calore catchment, but the correspondence is not perfect. While debris flows triggered by runoff were induced by the intensity of the storm, on the northern slope of Mt. Camposauro (Paupisi village), it seems that debris flows initiated by rilling and the accelerated soil erosion are mostly controlled by the geological nature of outcropping sequences and by land use. The spatial consistency of rill arrangements seems to suggest that agricultural techniques used for soil 
preparation could be among the main controlling factors of the location and characteristics of these debris flows that occur with heavy rainfall. All the recognized debris flows initiated by rilling are in flyschoid formations, especially where sandy and clay units crop out.

Moreover, it should be noted that slope instabilities, such as earth flows in clay and flysch terrains, are not as numerous as expected. This suggests that soil moisture content preceding the storm on 14-15 October 2015 was not high enough to produce the anticipated large extent of slope instabilities. Generally, these soil moisture conditions occur in the winter period.

Finally, this paper provides insights into natural disaster-induced effects following very intense storms in a wide area. This regional desk study and site investigation may help local authorities and the civil protection responsible for land planning and protection to (i) define areas that are more susceptible to flooding and hillslope processes and (ii) identify locations for which disaster recovery can be applied or preventive and mitigative measures can be adopted. These measures may be able to prevent or reduce the impact of future events.

Author Contributions: Conceptualization, P.R. and L.G.; Data curation, N.M., G.G. and G.R.; Formal analysis, P.R., N.M. and F.F.; Funding acquisition, F.M.G.; Investigation, N.M., G.G. and G.R.; Methodology, P.R., L.G. and F.F.; Project administration, P.R.; Supervision, P.R. and F.M.G.; Writing—original draft, P.R., L.G., N.M. and F.F.; Writing-review \& editing, P.R. All authors collaborated in carrying out this research.

Funding: This work was supported by the Benevento Province Authority.

Acknowledgments: We acknowledge the Agro-meteorological Center of the Campania Region and the Campania Region Civil Protection (Centro Funzionale Multirischi della Protezione Civile della Regione Campania) for providing rain data. Two anonymous reviews are acknowledged for their useful suggestions.

Conflicts of Interest: The authors declare no conflict of interest.

\section{References}

1. Knox, J.C. Large increase in flood magnitude in response to modest changes in climate. Nature 1993, 361, 430-432. [CrossRef]

2. Diodato, N. Climatic fluctuations in southern Italy since the 17th century: Reconstruction with precipitation records at Benevento. Clim. Chang. 2006, 80, 411-431. [CrossRef]

3. Coe, J.A.; Godt, J.W. Review of approaches for assessing the impact of climate change on landslide hazards. In Landslides and Engineered Slopes, Protecting Society Through Improved Understanding, Proceedings of the 11th International and 2nd North American Symposium on Landslides and Engineered Slopes, Banff, AB, Canada, 2-8 June 2012; Eberhardt, E., Froese, C., Turner, A.K., Leroueil, S., Eds.; Taylor \& Francis Group: London, UK, 2012; Volume 1, pp. 371-377.

4. Alvioli, M.; Melillo, M.; Guzzetti, F.; Rossi, M.; Palazzi, E.; von Hardenberg, J.; Brunetti, M.T.; Peruccacci, S. Implications of climate change on landslide hazard in central Italy. Sci. Total Environ. 2018, 630, 1528-1543. [CrossRef]

5. Guzzetti, F.; Stark, C.P.; Salvati, P. Evaluation of flood and landslide risk to the population of Italy. Environ. Manag. 2005, 36, 15-36. [CrossRef] [PubMed]

6. Petley, D. Global patterns of loss of life from landslides. Geology 2012, 40, 927-930. [CrossRef]

7. Aronica, G.T.; Brigandí, G.; Morey, N. Flash floods and debris flow in the city area of Messina, north-east part of Sicily, Italy in October 2009: The case of the Giampilieri catchment. Nat. Hazards Earth Syst. Sci. 2012, 12, 1295-1309. [CrossRef]

8. Fiorillo, F.; Diodato, N.; Meo, M.; Pagnozzi, M. Landslides and flash floods induced by the storm of 22nd November 2011 in northeastern Sicily. Environ. Earth Sci. 2018, 77, 602. [CrossRef]

9. Cevasco, A.; Diodato, N.; Revellino, P.; Fiorillo, F.; Grelle, G.; Guadagno, F.M. Storminess and geo-hydrological events affecting small coastal basins in a terraced Mediterranean environment. Sci. Total Environ. 2015, 532, 208-219. [CrossRef]

10. Del Prete, M.; Guadagno, F.M.; Hawkins, B. Preliminary report on the landslides of 5 May 1998, Campania, southern Italy. Bull. Eng. Geol. Environ. 1998, 57, 113-129. [CrossRef]

11. Calcaterra, D.; Parise, M.; Palma, B. Combining historical and geological data for the assessment of the landslide hazard: A case study from Campania, Italy. Nat. Hazard Earth Syst. 2003, 3, 3-16. [CrossRef] 
12. Revellino, P.; Guerriero, L.; Grelle, G.; Esposito, L.; Guadagno, F.M. Initiation and propagation of the 2005 debris avalanche at Nocera Inferiore (Southern Italy). Ital. J. Geosci. 2013, 132, 366-379. [CrossRef]

13. Napolitano, E.; Fusco, F.; Baum, R.L.; Godt, J.W.; De Vita, P. Effect of antecedent-hydrological conditions on rainfall triggering of debris flows in ash-fall pyroclastic mantled slopes of Campania (southern Italy). Landslides 2015, 13-15, 967-983. [CrossRef]

14. Violante, C.; Branca, G.; Esposito, E.; Tranfaglia, G. The 9 September 2010 torrential rain and flash flood in the Dragone catchment, Atrani, Amalfi Coast (Southern Italy). Nat. Hazards Earth Syst. Sci. 2016, 16, 333-348. [CrossRef]

15. Fiorillo, F.; Guerriero, L.; Capobianco, L.; Pagnozzi, M.; Revellino, P.; Russo, F.; Guadagno, F.M. Inventory of Vietri-Maiori landslides induced by the storm of October 1954 (Southern Italy). J. Maps 2019, 15. [CrossRef]

16. Salvati, P.; Bianchi, C.; Rossi, M.; Guzzetti, F. Societal landslide and flood risk in Italy. Nat. Hazards Earth Syst. Sci. 2010, 10, 465-483. [CrossRef]

17. Fiorillo, F.; Revellino, P. Le condizioni idrologiche che determinano lo sviluppo di frane superificiali nell'area sannita: Gli esempi del Gennaio 2003 e Marzo 2005. Giornale di Geologia Applicata 2006, 3, 129-136.

18. Revellino, P.; Grelle, G.; Donnarumma, A.; Guadagno, F.M. Structurally controlled earth flows of the Benevento province (Southern Italy). Bull. Eng. Geol. Environ. 2010, 69, 487-500. [CrossRef]

19. Diodato, N.; Soriano, M.; Bellocchi, G.; Fiorillo, F.; Cevasco, A.; Revellino, P.; Guadagno, F.M. Historical evolution of slope instability in the Calore River Basin, Southern Italy. Geomorphology 2017, 282, 74-84. [CrossRef]

20. Guerriero, L.; Focareta, M.; Fusco, G.; Rabuano, R.; Guadagno, F.M.; Revellino, P. Flood hazard of major river segments, Benevento Province, Southern Italy. J. Maps 2018, 14, 597-606. [CrossRef]

21. Valente, A.; Iscaro, C.; Magliulo, P.; Russo, F. The flood event in Benevento on 14th-15th October 2015: A short report. Rend. Online Soc. Geol. It. 2016, 38, 105-108.

22. Santo, A.; Santangelo, N.; Forte, G.; De Falco, M. Post flash flood survey: The 14th and 15th October 2015 event in the Paupisi-Solopaca area (Southern Italy). J. Maps 2017, 13, 19-25. [CrossRef]

23. Grelle, G.; Rossi, A.; Revellino, P.; Guerriero, L.; Guadagno, F.M.; Sappa, G. Assessment of debris-flow erosion and deposit areas by morphometric analysis and a GIS-based simplified procedure: A case study of Paupisi in the southern Apennines. Sustainability 2019, 11, 2382. [CrossRef]

24. D'Argenio, B.; Pescatore, T.S.; Scandone, P. Schema geologico dell'Appennino Meridionale. Acc Naz Lincei Quad. 1973, 183, 49-72.

25. Patacca, E.; Scandone, P. Geology of Southern Appennines. Boll. Soc. Geol. It. 2007, 7, 45-119.

26. Vitale, S.; Ciarcia, S. Tectono-stratigraphic setting of the Campania region (Southern Italy). J. Maps 2018, 14, 9-21. [CrossRef]

27. Donnarumma, A.; Revellino, P.; Grelle, G.; Guadagno, F.M. Slope Angle as Indicator Parameter of Landslide Susceptibility in a Geologically Complex Area. In Landslide Science and Practice. Volume 1: Landslide Inventory and Susceptibility and Hazard Zoning; Margottini, C., Canuti, C., Sassa, P., Eds.; Springer: Berlin/Heidelberg, Germany, 2013; Volume 2, pp. 425-433.

28. Guerriero, L.; Revellino, P.; Grelle, G.; Fiorillo, F.; Guadagno, F.M. Landslides and infrastructures: The case of the montaguto earth flow in southern Italy. Ital. J. Eng. Geol. Environ. 2013, 6, 459-466.

29. Magliulo, P. Quaternary deposits and geomorphological evolution of the Telesina Valley (Southern Apennines). Geogr. Fis. Dinam. Quat. 2005, 28, 125-146.

30. Rossi, F.; Villano, P. (Eds.) Valutazione delle Piene in Campania, pubbl n 1470 of CNR-GNDCI. In Progetto VAPI; CNR-GNDCI: Perugia, Italy, 1994.

31. Fiorillo, F.; Diodato, N.; Meo, M. Reconstruction of a Storm Map and New Approach in the Definition of Categories of the Extreme Rainfall, Northeastern Sicily. Water 2016, 8, 330. [CrossRef]

32. Jenkinson, A.F. The frequency distribution of the annual maximum (or minimum) values of meteorological elements. Q. J. R. Meteorol. Soc. 1955, 81, 158-171. [CrossRef]

33. Nguyen, T.H.; El Outayek, S.; Lim, S.H.; Nguyen, V.T.V. A systematic approach to selecting the best probability models for annual maximum rainfalls - A case study using data in Ontario (Canada). J. Hydrol. 2017, 553, 49-58. [CrossRef]

34. Fortelli, A.; Musto, F.M. Aree urbane e modalità di risposta agli eventi pluviometrici estremi: Analisi del fenomeno e strategie di salvaguardia. Territorio Della Ricerca Su Insediamenti E Ambiente 2015, 8, 153-167. 
35. Lee, K.O.; Flamant, C.; Ducrocq, V.; Duffourg, F.; Fourrié, N.; Davolio, S. Convective initiation and maintenance processes of two back-building mesoscale convective systems leading to heavy precipitation events in Southern Italy during HyMeX IOP 13. Q. J. R. Meteorol. Soc. 2016, 142, 2623-2635. [CrossRef]

36. McKee, T.B.; Doesken, N.J.; Kleist, J. The relationship of drought frequency and duration to time scales. In Proceedings of the 8th Conference on Applied Climatology, Anaheim, CA, USA, 17-22 January 1993; American Meteorological Society: Boston, MA, USA, 1993; pp. 179-184.

37. Hungr, O.; Leroueil, S.; Picarelli, L. The Varnes classification of landslide types, an update. Landslides 2014, 11, 167-194. [CrossRef]

38. Coe, J.A.; Kinner, D.A.; Jonathan, W.G. Initiation conditions for debris flows generated by runoff at chalk cliffs, central colorado. Geomorphology 2008, 96, 270-297. [CrossRef]

39. Santi, P.M.; deWolfe, V.G.; Higgins, J.D.; Cannon, S.H.; Gartner, J.E. Sources of debris flow material in burned areas. Geomorphology 2008, 96, 310-321. [CrossRef]

40. Godt, J.W.; Coe, J.A. Alpine debris flow striggered by a 28 July 1999 thunderstorm in the central Front Range, Colorado. Geomorphology 2006, 84, 80-97. [CrossRef]

41. Berti, M.; Genevois, R.; Simoni, A.; Tecca, P.R. Field observations of a debris flow event in the Dolomites. Geomorphology 1999, 29, 265-274. [CrossRef]

42. Selby, M.J. Hillslope Materials and Processes; Oxford University Press: Oxford, UK, 1993.

43. Iverson, R.M. The debris-flow rheology. In Proceedings of the 3rd International Conference on Debris-Flow Hazard Mitigation: Prediction and Assessment; Rickenmann, D., Chen, C.L., Eds.; Millpress: Rotterdam, The Netherlands, 2003; pp. 303-314.

44. Grelle, G.; Soriano, M.; Revellino, P.; Diodato, N.; Guadagno, F.M. Space-time prediction of rainfall-induced shallow landslides through a combined probabilistic/deterministic approach, optimized for initial water table conditions. Bull. Eng. Geol. Environ. 2014, 73, 877-890. [CrossRef]

(C) 2019 by the authors. Licensee MDPI, Basel, Switzerland. This article is an open access article distributed under the terms and conditions of the Creative Commons Attribution (CC BY) license (http://creativecommons.org/licenses/by/4.0/). 